EASTERN REVIEW 2020, T. 9

\author{
Sabrina P. Ramet \\ (iD) https://orcid.org/0000-0003-2843-3898 \\ Norwegian University of Science and Technology, Trondheim, Norway \\ Department of Sociology and Political Science \\ e-mail: sabrina.ramet@ntnu.no
}

\title{
Hegel, revolution, and the rule of law
}

\begin{abstract}
Georg Wilhelm Friedrich Hegel was one of the philosophic giants of the nineteenth century. Well versed in both ancient and more recent philosophical tracts, he rejected the individualism of Hobbes and Locke, as well as their notion that the state was an agency set up in the first place to protect life and property, and, drawing inspiration from Aristotle, outlined a vision of the state as an agency bound, in the first place, to protect the weak and the powerless. Hegel further rejected Kant's individualistic ethics and counseled that ethical behavior had to be understood as taking place in a social context, with real duties toward other people. For Hegel, an individual had rights and duties within the context of the family, in the community, and, as a citizen, vis-à-vis the state. He emphasized the network of duties in which each individual finds himself, urging political moderation and concern for the good of the entire community. He has been condemned as a proto-totalitarian, lauded as a democrat of sorts, and described variously as liberal, anti-liberal, authoritarian, conservative-monarchist, and constitutionalist. This essay will argue that Hegel came to champion a constitutional-legal order (Rechtsstaat) under an autocratic monarch, with protection for liberal values. The absolute authority of the monarch, thus, was limited to those powers which he needed in order to advance and protect the interests of the citizens of the realm.
\end{abstract}

Keywords: G.W.F. Hegel, philosophy, revolution, rule of law.

Hegel was a towering figure in nineteenth century philosophy, offering a vision of a world moving steadily in a progressive direction, toward greater freedom and ever greater understanding. It was an inspiring vision. But it was his methodology, combining geneticism, that is, a search for the origins of phenomena, and monism, the understanding that all facets of socio-political life are interconnected, with the dialectical method, a method which emphasizing 
the interaction of opposing factors in producing change, which influenced some of his contemporaries the most. Among those who were influenced by Hegel's questions and methodology was Karl Marx, and even today Hegel continues to have lingering influence, albeit often indirect, in the way scholars approach questions of historical, cultural, and political change.

In turning to Hegel, one encounters one of the most problematic and controversial thinkers of all time. ${ }^{1}$ While Hobbes, Rousseau, and for that matter Plato, as well as others, have seen their share of controversies, in the case of Hegel, commentators have argued over the most basic points, including:

- Whether Hegel was a democrat or an authoritarian.

- Whether Hegel should be seen as part of the liberal tradition or not.

- Whether Hegel is politically on the "left" (secular, pro-working class) or on the "right" (clerical, pro-establishment).

- Whether his methodology (dialectical monism) is inherently "progressive" and whether it can be somehow "separated" from his substantive points and conclusions.

- And even whether he should be understood as an "idealist" or as a "realist", or as standing somehow outside or above this dichotomy.

This last controversy is a bit surprising, given the intensity of Hegel's attack in The Phenomenology of Mind on Kant's idealism.

The French Revolution and the wars which it spawned constituted a watershed in European history and confronted political thinkers with the necessity of rethinking fundamental questions about political life. The French Revolutionary Wars, in which the Holy Roman Empire and Prussia were allied with countries fighting against revolutionary France, lasted from 1792 to 1802, while the Napoleonic Wars, which followed, lasted from 1803 to 1815. In 1819, Hegel wrote to a colleague, ${ }^{2}$ that in his 40 years he had seen too much fear and plenty of (dashed) hopes, and hoped for a time when the fears which had engulfed the continent would dissipate (Ritter, 1965: 18). It would have been impossible for anyone thinking seriously about politics in his day to have avoided reflecting upon the relationship between revolutionary aspirations and war. For Hegel, witnessing 23 years of virtually continuous conflict, war appeared to be a predictable, and in that sense "normal", recourse for states unable to resolve serious differences by peaceful means (Hegel, 1967a: 24).

${ }^{1}$ Among classic and noteworthy works on Hegel, one may mention (in chronological order): Ritter, 1965; Pelczynski (ed.), 1971; Avineri, 1972; Taylor, 1975; Shklar, 1976; Albrecht, 1978; Taylor, 1979; Wood, 1990; Beiser (ed.), 1993; Patten, 1999. Among recent, noteworthy books dealing with Hegel, one may mention (in alphabetical order): Cristi, 2005; Neuhouser, 2000; Pippin, 2008, 2011; Smith, 1989a; Taylor, 2008, 2015.

${ }^{2}$ Georg Friedrich Creuzer (1771-1858). 
But, in spite of its destructiveness, war was also regenerative, according to Hegel. "War has the higher significance," he wrote in Philosophy of Right (1967a: 210):

that by its agency, as I have remarked elsewhere, "the ethical health of peoples is preserved in their indifference to the stabilization of finite institutions; just as the blowing of the winds preserves the sea from the foulness which would be the result of a prolonged calm, so also corruption in nations would be the product of prolonged, let alone 'perpetual', peace.

War also served to unite the citizens of a state the most firmly around the state.

But the French Revolution, also unleashed the ill-famed Reign of Terror in which, between 27 June 1793 and 27 July 1794, some 1,285 persons were guillotined in Paris. In their quest for freedom, the French revolutionaries had let loose a "rage and fury of destruction," as Hegel put it (1967b: 604). Indeed, in his chapter on "Absolute freedom and terror", Hegel used the expression "absolute freedom" in a disparaging way, reflecting on how "absolute freedom puts itself on the throne of the world, without any power being able to offer effectual resistance" (Hegel, 1967b: 601). The French revolutionaries had proclaimed liberté, egalité, fraternité, and, Hegel noted, in the quest for "absolute freedom all social ranks or classes, which are the component" spiritual factors into which the whole is differentiated, are effaced and annulled" (Hegel, 1967a: 601). But, Hegel would argue later in Philosophy of Right, "'Men are made' unequal by nature... To oppose to this right a demand for equality is a folly of the Understanding which takes as real and rational its abstract equality and its 'ought-to-be'” (Hegel, 1967a: 130).

\section{His intellectual development}

Georg Wilhelm Friedrich Hegel (1770-1831) read widely in the works of classical antiquity (not only Plato, Aristotle, and Thucydides, but also Sophocles, whose play, Antigone, he translated into German) and of The Enlightenment (including Hobbes, Locke, Kant, Feder, Sulzer, Mendelssohn, and Montesquieu - indeed "the whole tradition of the Enlightenment") (Avineri, 1972: 1). In reading Kant, the young Hegel was impressed by Kant's thesis "that it is not possible to know 'things-in-themselves' or things as they really are" (Inyang, 2005). Hegel was also influenced by Kant's demonstration of the limits of human reason (Alcoff, 2010: 287). But already in his early years, Hegel did not find Kant's appeal to the categorical imperative sufficient, either to induce ordinary people to be moral or to guide people with any certainty to behavior which would be recognized as moral. On the contrary, Kant's approach to morality struck Hegel as hopelessly formalistic 
and ultimately leading to moral subjectivism (Kaufmann, 1954: 6). We shall return to Hegel's criticism of Kant below, in the section devoted to Natural Law.

The young Hegel was also exposed to the ideas generated in classical Greece, both through the works of Schiller and Goethe (especially the latter's Iphigenie) and through his exposure to the writings of Aristotle, which he read in the original Greek (Kaufmann, 1954: 14; Ferrarin, 2004: 395). In time he would embrace the Greek thinker's emphasis on the weight to be placed on the mores of the community - a position which represented an explicit repudiation of Kant's individualistic ethics.

In 1801, he was named Privatdozent at the University of Jena. The French Revolution was, by then, far advanced, and in the years 1806-1813, Hegel was broadly sympathetic to the principles for which the Napoleonic army was purportedly fighting. No German nationalist, he endorsed the decision taken at the Congress of Vienna (in 1814) not to establish a unified Germany. For him, the challenge to be met was not unification but political modernization; it was in this spirit that he expressed satisfaction with the reformed states of Bavaria, Württemberg, and Prussia, after the close of the Napoleonic Wars.

Both in his attitude to the Napoleonic code and in his response to German political reforms, Hegel was guided by his belief that the Enlightenment (especially Lockean) concept of the state which served, in the first place, to preserve property, however defined, was simply inadequate. Already in this period, in his manuscript, The German Constitution (1802) (Pelczynski, 1964: 13), Hegel shifted the emphasis from the protection of property to the organization for "common action and common defence." Eventually, in Reason in History, Hegel would define the state, or at least the progressive state, as the natural order of things, and insist that humankind realized the fullest freedom by operating within the legal framework of a strong state - a proposition which surely seemed self-evident in the revolutionary times in which he lived.

If the question of religious toleration may be seen as a barometer of left versus right, then, at least on this issue, Hegel was gravitating to the left. On this subject, he wrote that

in religion at least an identity might have been thought necessary, but... [s] imilarity of religion has no more prevented wars or united peoples into a state than dissimilarity of religion has in our day rent the state asunder (Hegel, 1964: 158-159).

In fact, Hegel emphasized that the state's control and regulation of the lives of citizens should be limited to what is necessary for it to function and for the defense of the homeland.

In March 1807, the same year that his Phenomenology of Mind was published, he moved to Bamberg to assume the post of editor of the local newspaper, Bamberger Zeitung. Marriage in 1811 was followed by the publication of Die 
Wissenschaft der Logik (The Science of Logic) in three volumes (1812-1816) (Hegel, 1969). At this point, he received offers of a post from the universities of Berlin, Erlangen, and Heidelberg. He chose Heidelberg; the major achievement during the years he spent in Heidelberg was the publication of his Enzyklopädie der philosophischen Wissenschaften im Grundriß (Encyclopedia of Philosophical Science in Outline) in 1817 (Wiedmann, 2003: 59). Then, in 1818, he accepted a renewed offer from the University of Berlin and moved to Berlin, where he lectured on the philosophy of history, the history of philosophy, the philosophy of religion, and aesthetics until his death in 1831. In 1821, came publication of his Grundlinien der Philosophie des Rechts, published in English under the title The Philosophy of Right. Hegel's last political work was his essay, On the English Reform Bill, published in 1831.

In August 1831, Berlin was hit by a cholera epidemic. Hegel left the city and took up temporary residence in Kreuzberg. When the school year began in October, Hegel returned to Berlin but, on 14 November of that year, he passed away. The official diagnosis was that he had died of cholera. At the funeral ceremony held at the University of Berlin, Philip Konrad Marheineke, one of the speakers, "likened Hegel's death to Christ's leaving the terrestrial realm in order to return to the ethereal heights of the spiritual kingdom" (Avineri, 1968: 135).

\section{Hegel and natural law}

Hegel "was engrossed in the reading of Kant... when the French Revolution broke out," and Hegel would subsequently define his own position on morality, in part, in response to Kant's framework (Pelczynski, 1964: 13; Kroner, 1921, 1924, 1941: 188-198). As early as 1802, Hegel published an essay on Natural Law in the Kritisches Journal der Philosophie, assaying a critique of Kant's moral rationalism and of British empiricism (as expostulated among others by Locke and Hume. In this essay, Hegel described what he considered "the breakdown of traditional Natural Law theories" (Avineri, 1972: 83). The heart of the problem, for Hegel, was what to make of the allegedly supreme authority of conscience and how to reconcile this with the claim of the state to political supremacy. Kant had confronted the problem head-on and had adopted the solution favored by Richard Hooker: i.e., where the government issues an immoral order, the individual should choose passive disobedience and, if need be, martyrdom; rebellion and revolution were ruled out. Hegel considered this solution of the problem inadequate. He believed there were at least two problems with Kant's formulation. The first was that Kant's categorical imperative can guide individuals only to consider what they, subjectively, believe would be universalizable. However, this pure subjectivity could actually result in actions which would be widely considered immoral, 
and could have injurious results (Mertens, 1995: 668). The second problem was that the appeal to the categorical imperative as the criterion for moral judgment elevates individual judgment above the rules and expectations of the community in which the individual lives, which, in Hegel's view, could only lead "to hatred of the law, to the destruction of the ethical community and to the ruin of the public order in which the law is supposed to function" (Mertens, 1995: 670). Now, having critiqued previous efforts to grapple with Natural Law, Hegel proceeded to lodge ethical life not in personal morality, let alone in religiosity, but in civic-mindedness, which is to say that, for Hegel, virtue consisted in an orientation toward the good of the community and an attention to one's concrete duties - to one's family, one's local community, and one's state - quite a difference from Kant's individual-centered categorical imperative!

\section{The Phenomenology of Mind (1807)}

Turgid in its prose and often defiantly obscure, The Phenomenology of Mind (Die Phänomenologie des Geistes) is Hegel's greatest masterpiece. In this work, one sees Hegel torn between his fear "that history is essentially catastrophic" (Lichtheim, 1964: 21) and his hope that history would provide a stage for a growth in humankind's awareness of its potentials and moral resources, and evolution of steadily more progressive forms of political association. It was, thus, with a retrospective glance to Hobbes (whose political philosophy Hegel reviled), that Hegel closed The Phenomenology... by constructing history as "at once the recollection and the Golgotha of Absolute Spirit, the reality, the truth, the certainty of its throne, without which it were lifeless, solitary, and alone" (Hegel, 1967b: 808).

In his Phenomenology..., he poured scorn on both German idealist Friedrich Wilhelm Joseph Schelling (1775-1854) and Kant, calling the latter's moral system "lifeless" while finding a tendency in Schelling to lead his converts into "the night in which, as we say, all cows are black - that is the very naïvete of emptiness of knowledge" (Hegel, 1967b: 79). ${ }^{3}$ Against these antagonists, Hegel promised to sketch a path to a higher truth, understood as a "bacchanalian revel, where not a member is sober" (Hegel, 1967b: 105).

The French Revolution, as Hegel understood it, was sparked, among other things, by a widespread desire for what he termed "universal freedom". But universal freedom - or perhaps one might say, the drive to establish universal freedom - can "produce neither a positive achievement nor a deed; there is left for it only negative action" (Hegel, 1967b: 604). Moreover, by shattering the pre-existing social order and proclaiming a doctrine of popular sovereignty in

\footnotetext{
3 Regarding "lifeless" (Hegel, 1967b: 108).
} 
which "the people" were expected to speak with a single voice, the revolutionaries opened the way for the use of terror against those who disagreed with their policies (Wokler, 1998: 43). In this regard, Hegel's fear of the consequences of the disintegration of political order was not so different from Hobbes', even if his solution was entirely different. On the other hand, Hegel differed from Hobbes and Kant in viewing war as not only unavoidable but also salutary, insofar as it induced individuals to think as citizens and to fight to protect the community. But revolution was another matter, because, unlike interstate war, it did not unite citizens in a common cause, but divided them. Revolution, thus, inexorably resulted in a fluidity in, and uncertainty about, social mores, a breakdown in consensus about the business of politics, and a condition in which violence, even against innocent bystanders, could not be excluded. Accordingly, in a passage striking both for its directness and for its clarity, Hegel reflected that, insofar as the aspiration toward "universal freedom" is associated with revolution,

[t]he sole and only work and deed accomplished by universal freedom is therefore death - a death that achieves nothing, embraces nothing within its grasp; for what is negated is the unachieved, unfulfilled punctual entity of the absolutely free self. It is thus the most cold-blooded and meaningless death of all, with no more significance than cleaving a head of cabbage or swallowing a draught of water (Hegel, 1967b: 605).

The reference to the "draught of water" was inspired by the not-so-uncommon practice, in French revolutionary times, of carrying out mass executions by drowning (Schmidt, 1998: 43). As for the cabbage heads - as Hegel saw - the revolutionaries experienced no more anxiety or remorse in guillotining those they came to view as enemies of the people than they had in chopping cabbage!

The problem with universal freedom, as understood by the French revolutionaries, was that it was conceptualized outside the framework of an ethical community, as if the individual should be seen as floating above the community, a law unto himself. Hegel would return to the legacy of the French Revolution in his Philosophy of Right, declaring there that

[Rousseau] takes the will only in a determinate form as the individual will, and he regards the universal will not as the absolutely rational element in the will, but only as a 'general' will which proceeds out of this individual... The result is that he reduces the union of individuals in the state to a contract and therefore to something based on their arbitrary wills, their opinion[s], and their capriciously given express consent... For this reason, when these abstract conclusions came into power, they afforded for the first time in human history the prodigious spectacle of the overthrow of the constitution of a great actual state and its complete reconstruction ab initio on the basis of pure thought alone, after the destruction of all existing and given material... and the experiment ended in the maximum of frightfulness and terror (Hegel, 1967a: 157). 
Hegel, indeed, had welcomed the Revolution initially, but recognized that it had ended in disaster, indeed in the transformation of the First Republic into the Empire established by Napoleon Bonaparte.

Hegel followed developments not only in Europe but also in Saint-Domingue, a French colony in the Caribbean, where black slaves launched a 15-year-long rebellion in 1791, finally establishing the independent state of Haiti in 1805 (Buck-Morss, 2000: 833-835). Coming just two years after the French revolutionaries had unfurled a banner calling for liberty and equality, the Caribbean rebellion drove home the point that calling "the Rights of Man" universal and demanding universal equality could only be hypocritical unless liberty and equality were extended to all humans, regardless of race or color. ${ }^{4}$ In fact, the section on "Lordship and Bondage" in The Phenomenology of Mind was inspired, at least in part, by events transpiring in Saint-Domingue (Buck-Morss, 2000: 842-854; Buck-Morss, 2009). Thus, in writing that "it is solely by risking life that freedom is obtained" (Hegel, 1967b: 233), Hegel was thinking precisely of the "life-and-death struggle" (Hegel, 1967b: 232) taking place in the Caribbean. In a passage which has puzzled some readers because of the abstract way it was formulated, Hegel wrote:

just where the master has effectively achieved lordship, he really finds that something has come about quite different from an independent consciousness. It is not an independent, but rather a dependent consciousness that he has achieved... But just as lordship showed its essential nature to be the reverse of what it wants to be, so, too, bondage will, when completed, pass into the opposite of what it immediately is: being a consciousness repressed within itself, it will enter into itself, and change round into real and true independence (Hegel, 1967b: 236-237).

Transposing this into the Caribbean context, it becomes clear that, insofar as the slave-holding class made itself dependent on slavery for its wealth (Buck-Morss, 2000: 847), its consciousness of itself as the dominant class was indeed dependent on holding the slaves in subjection. In this way, while "the master... gets the enjoyment" from this relationship, as Hegel put it, the master finds that his "consciousness... is mediated with itself through another consciousness" (Hegel, 1967b: 234).

${ }^{4}$ Hegel relied, in part, on the monthly journal Minerva for information about political developments worldwide and coverage of the Haitian rebellion in Minerva was especially thorough during the period from fall 1804 to the end of 1805, precisely at the time when Hegel, a regular reader of Minerva, was fully absorbed with the writing of The Phenomenology of Mind. It is likely, thus, that his famous phrase, "the owl of Minerva flies at dusk", refers not only to the Roman goddess of wisdom but also to the journal, and, in suggesting that wisdom might "fly" only at dusk, he had in mind that people respond to crises in a wise way only when the crisis has reached the point where it is almost too late. Humanity's belated and still hesitant response, in the 21 st century, to the perils associated with global warming and the destruction of the environment and its species may serve as an illustration of what would be included this reference. 


\section{The Philosophy of Right (1821)}

By the time Hegel assumed his post at the University of Berlin (in 1818), he had completely turned his back on the Enlightenment notion that the state should serve to protect property, which is to say, to protect the propertied classes. On the contrary, for Hegel, it was the state's duty to function as the protector of the weak and the propertyless. In The Philosophy of Right (PR), Hegel championed the rule of law, which he believed was gaining ground in Europe. Skeptics notwithstanding, it was not Hegel's intention to portray the Prussian monarchy as the highest embodiment of reason and the rule of law. Rather, his purpose in writing PR was to ground morality in the social context and to explain why freedom presumed and required the rule of law. On his view, moral behavior can be understood to mean behavior consistent with a community's moral consensus. On the surface, this might seem to imply moral relativism. But this is not the point. Rather, the point is that no individual should presume to construct a private morality from scratch, ignoring the moral consensus: such an approach can have disastrous consequences (Smith, 1989: 4-5; Pinkard, 1986: 222-223).

It was precisely here that Kant had erred, according to Hegel. By uprooting moral judgment from social context and appealing to the formulaic categorical imperative, Kant left it to each individual to decide for him - or herself whether a particular choice or action could be universalizable. The result was that Kant allegedly opened the door to extreme subjectivism in both moral and political decision-making (Mertens, 1995: 670; Ramet, 1983: 281-299). Bearing in mind that the political order (the state) was the guarantor of the community, and that it was only within a community that any person could realize his or her full potential, Hegel drew two inferences: first, patriotism, understood as loyalty to the community, had high ethical value; and second, freedom, in the sense in which we normally understand it, is possible only within a state operating according to the rule of law (a nomocracy). (When one considers the most likely alternatives - whether an anarchic society characterized by rivalry between plundering warlords or a dictatorship operating without any legal protections or a theocracy, in which self-designated prophets impose their vision of the will of God on everyone or a plutocracy in which the rich rule a state constructed to function as their agent - nomocracy looks preferable, especially for those who might not be associated with the ruling elites.)

Hegel was also committed to the idea that real equality had to include more than mere equality before the law. Accordingly, he championed progressive taxation as a device which might serve to promote economic equality. Yet, at times, Hegel's notion of the state seems utterly elusive. Consider, for example, the following passage from The Philosophy of Right: 
What is of the utmost importance is that the law of reason should be shot through and through by the law of particular freedom, and that my particular end should become identified with the universal end, or otherwise that state is left in the air. The state is actual only when its members have a feeling of their own self-hood and it is stable only when public and private ends are identical. It has often been said that the end of the state is the happiness of the citizen. That is perfectly true. If all is not well with them, if their subjective aims are not satisfied, if they do not find that the state as such is the means to their satisfaction, then the footing of the state itself is insecure (Hegel, 1967a: 281).

On the face of it, it might appear that Hegel's call for public and private ends to be rendered identical could be realized only at the expense of the individual. But the emphasis should, it seems to me, be placed on Hegel's notion that the purpose of the state is to foster "the happiness of the citizen" - a formulation not so remote from Jefferson's appeal to "life, liberty, and the pursuit of happiness" - and on his affirmation that "the law of reason should be shot through and through by the law of particular freedom" by which Hegel appears to have meant that the laws of the state should safeguard the particular freedom of each individual - an assertion which betrays agreement with, if not a debt to, Spinoza. But what is this happiness? Hegel tells us - in Charles Taylor's paraphrase - that "the happiest, unalienated life for man, which the Greeks enjoyed, is [one] where the norms and ends expressed in the public life of a society are the most important ones by which its members define their identity as human beings" (Taylor, 1975: 383). Happiness, in brief, consists in contentment with the norms and ends expressed in public life.

This formulation already points to Hegel's conviction that the state did not exist merely, or even primarily, to serve the interests of individuals. In paragraph 258 of Philosophy of Right, Hegel rejected the Lockean idea that the ultimate purpose of the state could be reduced to protecting property and securing personal freedom, a notion which, he thought, confused the state with civil society. Where Hobbes and Locke had described the state as a contract between the sovereign and his subjects, Hegel argued that "the state is not a contract at all; nor is its fundamental essence the unconditional protection and guarantee of the life and property of members of the public as individuals" (Hegel, 1967a: 71). Rather, its main function was to guarantee the ethical life of the community - which is say that people behave in accordance with the moral law and respecting their duties to each other (Taylor, 1979: 86). Social contract theory - in which connection he mentioned also Rousseau (Hegel, 1967a: 157) - was founded on an atomistic view of society, offering not so much a false interpretation as one that is only partial. In Hegel's view, "the Enlightenment... sees the world only as a heap of objects, open to human scrutiny and use; it does not see it also as manifestation, the emanation of reason" (Taylor, 1975: 401). ${ }^{5}$ This, in turn, provides a clue as to the affinity of

\footnotetext{
${ }^{5}$ I have modified the text, moving "only" from its original position just before "sees".
} 
liberalism for a utilitarian-materialist perspective on the world. But, married to an atomistic model of free enterprise - under the slogan of "the invisible hand" - social contract theory ends in self-contradiction. On the one hand, it preaches that laissez faire economics allows each individual maximum autonomy to chart his or her own course. But, on the other hand, each individual operates within a system to which s/he contributes only minor input, a system which is the product of competition rather than of vision ("will" in Hegel's terminology). In Hegel's view, thus, an individual is actually less free in a laissez faire system than $\mathrm{s} / \mathrm{he}$ is in a society in which the state, acting on behalf of all citizens, fashions rules which operate in the interest of all (Taylor, 1975: 401).

Like many persons in his era, Hegel believed that religion was "an integrative factor in the state" (Hegel, 1967a: 168) and could condition people to ethical behavior. Hence, it is not surprising to find him suggest, in Philosophy of Right, that "the state should even require all its citizens to belong to a church", though he immediately adds, "a church is all that can be said, because since the content of a man's faith depends on his private ideas, the state cannot interfere with it" (Hegel, 1967a: 168). Thus, the state cannot be confessional, and state neutrality in matters of religion is upheld. In this, he rejected Rousseau's appeal to a civic religion. Indeed, in an early essay, Hegel had declared that "nothing is more intolerable than publicly employed guardians of morals" (Nohl, 1907: 45 cited in Kaufmann, 1954: 7-8). While he would adopt a more friendly disposition toward Christianity in PR, he had rejected, in his early writings, any doctrines which claimed to "transcend reason without contradicting reason" (Nohl, 1907: 53 cited in Kaufmann, 1954: 8), and seemed, if anything, to admire the Olympian religion of classical Greece.

But Hegel insisted that there could be no tolerance for the non-performance of civic duties, even if the recalcitrants should justify their non-performance in terms of their religious faith. Here Hegel appeared to be criticizing those religious sects which objected to public oaths, to the performance of military service, and so forth. Hegel's criticism was direct and harsh:

Those who 'seek guidance from the Lord' and are assured that the whole truth is directly present in their unschooled opinions, fail to apply themselves to the task of exalting their subjectivity to consciousness of the truth and to knowledge of duty and objective right. The only possible fruits of their attitude are folly, abomination, and the demolition of the whole ethical order, and these fruits must inevitably be reaped if the religious disposition holds firmly and exclusively to its intuitive form and so turns against the real world and the truth present in it in form of the universal, i.e., of the laws... (Hegel, 1967a: 167).

Yet, like Rousseau, Hegel saw the ethical life of the community realized within the framework of the state; for both thinkers, either religious associations support 
the state (in which case they are to be evaluated positively) or they undermine the state (in which case they do not deserve to be tolerated and indeed, should not be tolerated). Hegel was quite explicit on this point, telling us:

the state is not a [mere] mechanism but the rational life of self-conscious freedom... On the other hand, the doctrine of the church is not purely and simply an inward concern of conscience. As doctrine it is rather the expression of something, in fact the expression of a subject-matter which is most closely linked, or even directly concerned, with ethical principles and the law of the land. Hence, at this point the paths of church and state either coincide or diverge at right angles (Hegel, 1967a: 170).

\section{The Philosophy of History (1830-1831)}

Hegel's point of departure in The Philosophy of History was that the world operates according to rationally comprehensible principles. It followed, for him, that "in world history, things have come about rationally" (Hegel, 1953: 11). This did not mean that people should be presumed to act rationally or even that some ultimate rational purpose is served by people's irrational actions. What it meant, for Hegel, rather was that one could understand politics and history in terms of certain scientific laws - which had the consequence that political science could be possible. And yet, Hegel's meaning was not limited to that. In fact, he also wanted to suggest that, in some larger sense, history unfolds in accordance with a rational principle, and hence he wrote that

world history... has proceeded rationally, $[\ldots]$ it represents the rationally necessary course of the World Spirit, the Spirit whose nature is indeed always one and the same, but whose one nature unfolds in the course of the world (Hegel, 1953: 12).

Hegel at once connected this point of view with that of the pre-Socratic philosopher Anaxagoras (Hegel, 1967b: 114), whom he credited with first having viewed reason as a guiding principle in world affairs.

He then asked what is the purpose of history and answered that its purpose was the development of the idea of freedom. Indeed, these two ideas - freedom and reason - are linked in the state, which Hegel described as "that actuality in which the individual has and enjoys his freedom," although he immediately qualified this by adding, "but only as knowing, believing, and willing the universal" (Hegel, 1953: 49). For Hegel, it made no sense to talk of either freedom or duty outside an ethical order, which is to say, outside a community. Hence, "[t]he right of individuals to be subjectively destined to freedom is fulfilled when they belong to an actual ethical order, because their conviction of their freedom finds its truth in such an objective order" (Hegel, 1967a: 109). Moreover, it is in duty that "the 
individual finds his liberation... from dependence on mere natural impulse... [and] from the indeterminate subjectivity which... remains self-enclosed and devoid of actuality" (Hegel, 1967a: 107). What he meant more specifically was that it is through "the mutual constraint of all" that "a small space of liberty for each" is assured and that, therefore, "law, morality, the State, and they alone, are the positive reality and satisfaction of freedom" (Hegel, 1953: 50). But if law is the foundation of freedom and the realization of the purpose of history, then one is entitled to ask whether any kind of law will do, and any kind of state, or whether some laws are better than others. His answer is predictable, viz., that those laws are best where the state comes the closest to realizing reason in its codes. He therefore wrote that "The laws of ethics are not accidental, but are rationality itself" (Hegel, 1953: 50). As already emphasized, Hegel did not claim that the Prussian state was the highest embodiment of rationality. Indeed, Hegel advocated the use of trial by jury and the idea that all citizens be eligible for civil service - features not found in Prussia at the time (Brooks, 2007: 92).

Hegel's viewpoint was explicitly teleological, with history seen as a gradual but steady ripening of knowledge, morality, and freedom. Thus, as he put it in Philosophy of Right,

world history is not the verdict of mere might, i.e., the abstract and non-rational inevitability of a blind destiny. On the contrary, since mind is implicitly and actually reason, and reason is explicit to itself in mind as knowledge, world history is the necessary development, out of the concept of mind's freedom alone, of the moments of reason and so of the self-consciousness and freedom of mind. This development is the interpretation and actualization of the universal mind (Hegel, 1967a: 216).

In one of his most famous passages, directed against Kant, Hegel expanded on his vision of law based on reason. Here he offered a vision of the state as

the externally existing, genuinely moral life. It is the union of the universal and essential with the subjective will, and as such it is Morality. The individual who lives in this unity has a moral life, a value which consists in this substantiality alone... [This means that the individual's] particular will has no validity... What counts is the common will (Hegel, 1953: 50).

Even more controversially, as already noted, Hegel added that the state did not exist to serve individuals, and that he would prefer to say that the state is "the end" and the citizens its means! But then he immediately cast this formulation aside, noting that the end-means formula was misleading; instead, he now suggested that "All the value man has, all spiritual reality, he has only through the state" (Hegel, 1953: 52). This passage has given rise to various misconstruals of Hegel as an authoritarian. But such misreadings of Hegel depend upon a misunderstanding of what Hegel meant by the word "Staat" (state). As Z.A. Pelczynski (1971: 10), 
Leon Goldstein (1962: 61-66), and Kenneth Westphal (1993: 256-261) have noted, Hegel used the term "Staat" with a much broader meaning than what we customarily mean by "the state"; in his usage, the term referred alternatively to the political state (the government), to civil society (the citizens collectively), and to the "ethical community", which is to say the society as a shared culture. By "civil society", Hegel meant

a system of public authorities and autonomous bodies existing to further the private interests of individuals or their more or less organization groups... [and] also a network of spontaneous, private relations established within the framework of the law by individuals pursuing their particular ends (Pelczynski, 1971: 10).

What Hegel had in mind, thus, in emphasizing "the state" was to stress what Aristotle had previously stressed, viz., that people fulfil themselves within a community and derive their culture from that community; Hegel's originality here consisted in his further argument that it was only through the cultural and political ties achieved in a state community that a people could aspire toward a higher level of freedom in the fullest sense (Durán De Seade, 1979: 370; Ferrarin, 2007). It followed that notions of freedom which emphasized individual preferences were misguided; true freedom meant only the possibility to live in a moral way (Hegel, 1953: 55; Neuhouser, 2000: 249). And this, in turn, meant that one could be free only if one participated, through informed give and take, in determining the moral standards of the society. By contrast, ignoring the moral views of others or defiantly doing as one pleases could not be a route to any real freedom (as Raskolnikov discovered in Fyodor Dostoyevsky's novel, Crime and Punishment).

But again, there could be misunderstanding in stressing the common will and thus Hegel added the caution that one should not refer anything to "the people". Hegel did not believe in the Enlightenment notion of popular sovereignty, viewing sovereignty rather as a facet of the state itself. As he had remarked earlier in The Philosophy of Right, sovereignty, in his view,

is the strictly individual aspect of the state, and in virtue of this alone is the state one... Hence this absolutely decisive moment of the whole is not individuality in general, but a single individual, the monarch (Hegel, 1967a: 181).

A constitution, accordingly, is embodied in the monarch and does not reflect the conscious choices and preferences of a people, according to Hegel, but should be seen rather as a measure of the level of "the people's spiritual development" (Hegel, 1953: 60). 


\section{Hegel and liberal democracy}

In Philosophy of Right, Hegel stated explicitly his skepticism about the notion that popular election of representatives would conduce to a government working in the best interests of the people generally. In his view, people are simply too ignorant to be trusted to pursue their own interests and are inclined to "irrational, barbarous, and frightful" behavior (Hegel, 1967a: 198). This led him to conclude that "it is not essential that the individual should have a say as an abstract individual entity [in the affairs of government]; on the contrary, all that matters is that his interests should be upheld in an assembly which deals with universal issues" (Hegel, 1967a cited in Tunick, 1998: 517). At the same time, in a passage which may reflect some inconsistency on Hegel's part or perhaps merely some subtlety on his part, he referred, in his essay The English Reform Bill, to "the right of the people to participate in public affairs...The exercise of this right is a lofty duty" (Hegel, 1964: 318). It should be stressed, however, Hegel's political vision did admit of rights and he allowed that people were under no obligation to respect bad laws or institutions (provided that they did not judge the laws on an individual basis). Insofar as Hegel viewed historical progress in terms of a widening vision of human freedom, it followed that people are free only when they recognize the laws of their community as rational and appropriate. For Hegel, "[a] practice or law is rational, and commands our commitment, if it is part of a system of ethical life that is (1) coherent and (2) functional and enduring, and (3) if we are 'at home' in this system of ethical life" (Tunick, 1998: 522). The notion of home is crucial here and refers to the community's consensus, or perhaps, better said, general sense, that the laws and institutions of the state reflect the values of the community "in a system of ethical life that promotes freedom" and are broadly speaking rational (which is to say, not obviously irrational, whether in the Aristotelian sense of working solely in the interests of the ruling elite or in a more commonsensical understanding of what constitutes irrationality) (Tunick, 1998: 517-526). Where that is not the case and where the laws and institutions serve as instruments of oppression - as in the France of King Louis XVI or the French colony of Saint-Domingue - then, for Hegel, "the poor have... a right to rebel against the order which prevents the realization of their freedom" (Henrich, 1983 cited in Tunick, 1998: 529).

To understand Hegel's response to the notion of mass participation in political life, it is critical once again to remember that he was writing during and immediately after the French Revolution and its attendant wars. On the positive side, Hegel saw that the French Revolution marked the first occasion in European history when there was a recognition of "the right of all citizens to have their welfare needs met and their personality respected, and with this the right of all human beings to be free" (Tunick, 1998: 524). He thus justified non-compliance, 
resistance, and even rebellion when the state and its laws were unjust and when such actions were necessary in order to put the state (the community and its laws) on a rational footing. But, in spite of its role in making people aware of their rights and in spurring European states to rethink their politics, the French Revolution was a failure, in Hegel's view. As already noted, he recoiled at the terror which that revolution unleashed, blamed Rousseau's writings for having played a "pernicious role" in the revolution, and concluded that the whole notion of popular sovereignty was profoundly dangerous (Suter, 1971: 55-56, 62). Yet, late in life, reflecting on the French Revolution, Hegel commented, with words that sound somewhat nostalgic, "A sublime feeling ruled that time, an enthusiasm of the spirit thrilled through the world, as if we had finally come to the real reconciliation of the divine with the world" (Hegel cited in Taylor 1975: 424).

This musing, whatever else it reveals, confirms once again that Hegel cannot be construed as a conservative in the nineteenth-century understanding of that term.

Against the individualism which he identified with the French Revolution and with Kant's moral philosophy, Hegel posited an organic conception of the state, in which customs, traditions, and ethical life were accorded their place. On this point, he looked to the ancient Greek polis as a model of a society in which there was no diremption between the ethics of the community and the ethics of the individual. Against the notion of mass participation in politics, Hegel advocated a constitutional monarchy with limited popular participation but with government working in the interests of the people. To be sure, Hegel supported the establishment of an Estates Assembly, but his idea was that this would be a consultative rather than a legislative body, affording its deputies the possibility of informing themselves about the affairs of state and offering reflections for the executive to consider (Westphal, 1993: 261). Moreover, Hegel did not want to see such deputies elected as he feared that popular elections would only encourage people to promote their ostensible short-term and particular interests over the interests of the community as a whole (Westphal, 1993: 261). Hegel was, thus, no advocate of democracy. But he was no advocate of authoritarianism either, if, by that term we may understand a system in which a monarch or despot rules in his own interest and without regard to the laws of the land. Hegel was a legitimist, who believed that the monarch should succeed to the throne according to the rule of primogeniture (Christi, 2005: 12), and, far from advocating that the law could be set aside, he urged that the monarch rule within the framework of the constitution and the law. He could be described as an advocate of nomocracy and of legitimate government (as he understood legitimacy), and as hostile to irrational rule, which he equated both with authoritarianism and with mass participation democracy. In this context, it is worth stressing that Hegel explicitly called for the separation of Church and state (Hegel, 1967a: 173), and that he, likewise explicitly, endorsed the principle of the separation of powers, championed earlier by Montesquieu. "Amongst current ideas," he wrote in PR, 
mention may be made...of the necessity for a division of powers within the state. This point is of the highest importance and, if taken in its true sense, may rightly be regarded as the guarantee of public freedom....[However,] if the powers (e.g. what are called 'Executive' and the 'Legislature') become self-sufficient, then as we have recently seen on a grand scale, the destruction of the state is forthwith a fait accompli (Hegel, 1967a: 175).

A few pages later, Hegel acknowledged his debt by writing that "here again, as in so many places, we must recognize the depth of Montesquieu's insight in his now famous treatment of the basic principles of... government" (Hegel, 1967a: 177).

Again, Hegel insisted that both the laws and the judicial system itself be comprehensible to the citizens (Stillman, 1980: 630; Hegel, 1967a: 138), that the laws be published and enforced (Hegel, 1967a: 142), that provision be made for public education (Hegel, 1967a: 148), and that individuals have not only duties to the state but also rights against it (Hegel, 1967a: 161). Addressing the issue of poverty, he argued that the best solution was to provide work for the poor, although, to the extent that that might not be possible, they should be supported either by public resources or by having "the burden of maintaining them at their ordinary standard of living... directly laid on the wealthier classes" (Hegel, 1967a: 150).

But what about liberalism? Here the debate remains lively. It is clear that Hegel defended the rule of law and individual rights (Wood, 1993: 221). ${ }^{6} \mathrm{He}$ advocated the separation of Church and state with religious tolerance (within some limits) (Hegel, 1967a: 167-168, 173; Jaeschke, 1981: 127-145, 129-131, 134, 142), and one may even find a passing reference to respect for the harm principle (Hegel, 1967a: 206-207). But he imbued these terms with his own meaning and gave them a weighting which is different from, let us say, the Lockean heritage or the Kantian legacy; moreover, he placed these principles within a framework radically different from that of classical liberalism. Furthermore, although he paid tribute to the importance of individual rights, such rights were set in a context in which the individual's duties to the state received equal stress. Again, as we have already seen, Hegel rejected the social contract theory of the state. One of the problems with social contract theory is the notion of the contract itself, which suggests that people may opt in or out, whereas in reality people are born into a state and, unless they emigrate, do not make the decision to opt in or out of one or another state, and even for those immigrating into a state they choose, such immigrants are not in a position to negotiate a contract with that state. Closely connected to this is the assumption, which Hegel attributed to social contract theorists, that the purpose of political association is the promotion of the interests of individuals (Neuhouser, 2000: 176). In Hegel's mind, this construal of the

\footnotetext{
${ }^{6}$ See also Hegel's comment, "individuals have duties to the state in proportion as they have rights against it" (Hegel, 1967a: 161).
} 
state was utterly unacceptable; against this individualistic concept of the state he argued that the state, when founded on the rule of law and when committed to the aforementioned core liberal values, had a value in its own right, even to the extent that we might consider the state to be a kind of ethical community (Smith, 1989: 145-147). This meant, as we have seen, that the protection of private property could not be construed as a purpose of the state. In his view, it was precisely due to the overemphasis on individual rights and especially the right to accumulate property that the American Republic had gone off track. As he saw it, the culture of the American people was characterized by "the endeavour of the individual after acquisition; commercial profit, and gain; [and] the preponderance of private interest," with the individual devoting himself "to that of the community only for [his] own advantage" (Hegel, 1962: 85 cited in Kelly, 1972: 6).

Hegel also rejected the classical liberal theory of natural rights which - erroneously in his view - argued that such rights could exist prior to or outside the framework of civil society (Smith, 1986: 122-123). To Hegel's mind, such a concept of rights was unutterably abstract. This is not to say that Hegel turned his back on the Natural Law tradition. Rather, as Abel Garza Jr. has written, he sought to assimilate it to his concept of the state as an ethical community, rejecting the notion "that natural laws are premised on an asocial, atomistic human nature" (Garza, Jr., 1990-1991: 387). This led directly to a third objection which Hegel registered against liberalism, especially in its Kantian incarnation, viz., that the kind of morality which it encouraged referred only to good intentions and was not grounded either in the customs and practices of the community or in a recognition of the network of concrete relations of obligation in which any person finds him - or herself. Again, for Hegel, social contract liberalism encouraged excessive attention to rights and insufficient attention to duties - Kantian theory notwithstanding. Thus, for Hegel, "It is uncultured people who insist most on their rights, while noble minds look on other aspects of the thing" (Hegel, 1967a: 235). A fourth error committed by classical liberalism, according to Hegel, was that it posited (as per John Locke's Second Treatise) that, in establishing a state, people gave up their natural right to punish offenders; for Hegel, however, to the extent that people have a right to respond to offenses outside the framework of the state, that right takes the form of a right to revenge, not a right to punish, since punishment is, strictly speaking, a function of an organized political authority (Stillman 1974: 1090). A fifth error, of which Hegel found Hobbes and Locke guilty, was that they had attempted to derive rights from needs (Smith, 1989: 68-70) - i.e., to derive an "ought" from an "is" (a derivation generally considered impossible by philosophers). The final error committed by classical liberalism is the argument that the state limits people's natural freedom and autonomy. According to Hegel, the relationship of the state to freedom is precisely the opposite of what he thought classical liberalism supposed, in that the state is the prerequisite of human freedom and the agency through which freedom may be achieved and guaranteed. And in 
considering freedom, Hegel placed especial emphasis on a person's freedom to choose his or her line of work.

But for all of Hegel's criticism of Locke and Kant, as well as Hobbes and Rousseau, some scholars have argued that it does not automatically follow that Hegel should be seen as outside the liberal tradition. There are at least two other possibilities. The first, argued by Steven Smith, is that Hegel might be seen as having articulated a position midway between liberalism and its critics (Smith, 1986: 121). The second, argued by F.R. Cristi (1989: 717-738), is to view Hegel as having argued for a conservative strain of liberalism, a strain which, to use terminology favored by Hegel's translators, both "cancels and preserves" the most basic elements of the liberal tradition. In Cristi's view, the monarch is an essential linchpin of liberalism in Hegel's system in that the monarch serves as a barrier to the revolutionary chaos which modern civil society might otherwise throw up. What both of these perspectives share is a recognition that Hegel was responding to the challenge posed by the French Revolution as well as to the theories of Montesqueiu, Locke, and Kant and wanted to improve on their theories, safeguarding values which these earlier thinkers had considered important. Hegel had considerable esteem for Montesquieu's The Spirit of the Laws, which he described as "immortal" (Senigaglia, 2007: 39). But Hegel had some reservations concerning Montesquieu's call for a strict separation of powers, believing that the competition between the Estates-Assembly (the legislature) and the Directorate (the executive) in the first phase of the French Revolution had proven destructive (Senigaglia, 2007: 47).

For Hegel,

The fundamental characteristic of the state as a political entity is the substantial unity, i.e. the ideality, of its moments... That is to say, sovereignty depends on the fact that the particular functions and powers of the state are not self-subsistent or firmly grounded either on their own account or in the particular will of the individual functionaries, but have their roots ultimately in the unity of the state as their single self (Hegel, 1967a: 179-180).

Although there is no suggestion that Hegel was thinking of the young American Republic, it is clear that his perspective on the separation of powers was very different from that of Jefferson and Madison.

A third possibility, which is entirely compatible with Smith's interpretation, is to construe Hegel as emphasizing the social contexts (family, community, state) in which people find themselves. This reflects the brunt of Hegel's charge against Kant who, in his view, sketched out a moral theory in which the individual is called upon to act on the basis of rational consistency and respect for other people, but in which no account is taken of the fact that there are social mores presented ready-made to people already as they grow up (Pinkard 1986: 221-222; Smith, 1989: 71-72). In Hegel's view, duties "are far less a product of deliberate reflection 
than of social and cultural development" (Smith, 1989: 72). Hegel, thus, emerges as a champion of reformed monarchism - a formula which saw some currency beginning with the reigns of the liberal Habsburg monarchs Maria Theresa and Joseph II in the late eighteenth century and which continued to be considered viable in some quarters well into the nineteenth century.

\section{Conclusion}

One aspect of Hegel's political philosophy which has attracted comment is Hegel's stress on the importance of absolute monarchy precisely to protect a liberal political order. In Hegel's view, democracy could threaten liberal values or, to put it differently, the fewer constraints on democracy, the greater the potential threat to liberalism. For anyone who remembers John Stuart Mill's warning about the "tyranny of the majority", Hegel's own warning should not seem strange. Indeed, as F.R. Cristi has written,

Hegel fashions civil society according to a rigorously liberal framework, conceived in terms of the freedom of individuals. Individual freedom is understood as the right of each person to acquire property and enter into contractual agreements with other persons (Cristi, 1983: 609).

Hegel offered the institution of an absolute monarch, thus, as the anchor of the Rechtsstaat (nomocracy) and as "the best safeguard against the democratization of civil society" (Cristi, 1983: 610). Here it is important to emphasize an important distinction between Hegel and Hobbes. Whereas the English thinker placed the monarch above the law, for Hegel, the monarch was the embodiment and guarantor of the law. And further, the majesty and authority of the monarch serve as a bulwark against the diremptive even fracturing, atomistic tendencies associated with the self-seeking of the business classes. To cite Cristi once again, civil society, the domain of the business classes, embodies

the dissociation of ethical life and its principles [which] are by definition opposed to those of the family and the state... An absolute monarch in whose hands is concentrated the totality of political power is needed, according to Hegel, in order to secure the total depolitization of civil society (Cristi, 1983: 618).

The monarch is therefore - to reiterate the point for emphasis - is not democratic, but $\mathrm{s} /$ he is potentially the best available guarantor of a liberal order. However, all of this would break down, according to Hegel, if the monarchy were to be an elective office. In order to stand apart and even above civil society, the monarch must come to office in accordance with the rules of dynastic succession, in the first place primo geniture. 
To view Hegel only through the lenses of those who responded to him - whether Feuerbach and the other Young Hegelians, or Marx and Engels, or the so-called Old Hegelians - is to trivialize him. Hegel's importance, indeed his greatness, must be sought in the corpus of work he left behind, including in his success in grappling with the issues of his day. Here one finds a vision of history as progress in knowledge and growth in moral understanding - ideas which he inherited from Immanuel Kant - but also a vision of a flowering of human freedom to be achieved not by stripping away the functions of the state (a strategy which could only harm the most vulnerable sectors of society), but by refining its normative framework so that politics should become less and less about the rule of men and women, and more and more about the rule of law, with such law corresponding to the moral consensus and level of progress achieved by the given society. What Hegel bequeathed to the world was, in short, an alternative vision of political life - a vision of political life which rejected the notion that the state should be seen "as a necessary evil to be endured for the sake of civil peace and the enjoyment of private goods" (Smith, 1989: 135) and emphasized rather the fact that human freedom itself is realized only within the context of the Rechtsstaat. I find myself in agreement, thus, with Steven Smith's conclusion that "Hegel's chief accomplishment has been to show that the state and community are not just a precondition for, but [also] a dimension of, freedom" (Smith, 1989: 233). For the state, properly understood, "is ultimately a meeting of minds, since it depends on a common cultural history and a sense of civic identity... [and is charged with] the positive function of promoting a way of life" (Smith, 1989: 233).

\section{References}

Albrecht, R. 1978. Hegel und die Demokratie. Bonn: Bouvier Verlag Herbert Grundmann. Alcoff, L. 2010. Continental Epistemology. In: J. Dancy, E. Sosa, M. Steup (eds.). A Companion to Epistemology, 2nd ed. Vol. 4. Chichester: Wiley-Blackwell, pp. 287-292. Avineri, S. 1968. Hegel Revisited. Journal of Contemporary History 3(2), pp. 133-147.

Avineri, S. 1972. Hegel's Theory of the Modern State. Cambridge: Cambridge University Press.

Beiser, F.C. (ed.). 1993. The Cambridge Companion to Hegel. Cambridge: Cambridge University Press.

Brooks, T. 2007. No Rubber Stamp: Hegel's Constitutional Monarch. History of Political Thought 28(1), pp. 91-119.

Buck-Morss, S. 2000. Hegel and Haiti. Critical Inquiry 26(4), pp. 821-865.

Buck-Morss, S. 2009. Hegel, Haiti, and Universal History. Pittsburgh, Pennsylvania: University of Pittsburgh Press.

Cristi, F.R. 1983. The Hegelsche Mitte and Hegel's Monarch. Political Theory 11(4), pp. 601-622. 
Cristi, F.R. 1989. Hegel's Conservative Liberalism. Canadian Journal of Political Science/Revue canadienne de science politique 22(4), pp. 717-738.

Cristi, F.R. 2005. Hegel on freedom and authority. Cardiff: University of Wales Press.

Dancy, J., Sosa, E., Steup, M. (eds.). 2010. A Companion to Epistemology, 2nd ed., Vol. 4. Chichester: Wiley-Blackwell.

Durán De Seade, E. 1979. State and History in Hegel's Concept of People. Journal of the History of Ideas 40(3), pp. 369-384.

Ferrarin, A. 2004. Hegel and Aristotle. Cambridge: Cambridge University Press.

Ferrarin, A. 2007. Hegel and Aristotle. Cambridge: Cambridge University Press.

Garza, Jr. A. 1990-1991. Hegel's Critique of Liberalism and Natural Law: Reconstructing ethical life. Law and Philosophy 9(4), pp. 371-398.

Goldstein, L.J. 1962. The Meaning of 'State' in Hegel's Philosophy of History. The Philosophical Quarterly 12(46), pp. 60-72.

Hegel, G.W.F. 1953. Reason in History. Trans. R.S. Hartman. Indianapolis: Bobbs-Merrill Co.

Hegel, G.W.F. 1967a. Philosophy of Right. Trans. T.M. Knox. London \& Oxford: Oxford University Press.

Hegel, G.W.F. 1967b. The Phenomenology of Mind. Trans. J.B. Baillie. New York: Harper \& Row.

Hegel, G.W.F. 1969. Hegel's Science of Logic. Trans. A.V. Miller. London: Allen \& Unwin. Reissued by Humanity Books of New York.

Hegel, G.W.F. 1971. The German Constitution. In: Hegel's Political Writings. 1964. Trans. T.M. Knox. Oxford: Clarendon Press, pp. 6-258.

Henrich, D. 1983. Vernunft in Verwirklung. In: G.W.F. Hegel. Philosophie des Rechts. Die Vorlesungen von 1819/20 in einer Nachschrift. D. Henrich (ed.). Frankfurt am Main: Suhrkamp.

Inyang, J. 2005. Hegel's Idea of the Absolute and African Philosophy. In: Ibuanyidanda (Complementary Reflection), African Philosophy and General Issues in Philosophy, http://www.frasouzu.com/Issues \%20and\%20Papers\%20Hegel\%20The\%20Absolute\%20and\%20African\%20Philosophy.html (accessed 15.08.2011).

Jaeschke, W. 1981. Christianity and Secularity in Hegel's Concept of the State. Journal of Religion 61(2), pp. 127-145.

Kaufmann, W.A. 1954. Hegel's Early Antitheological Phase. The Philosophical Review 63(1), pp. 3-18.

Kelly, G.A. 1972. Hegel's America. Philosophy \& Public Affairs 2(1), pp. 3-36.

Kroner, R. 1921, 1924. Von Kant bis Hegel. 2 Vols. Tübingen: Mohr.

Kroner, R. 1941. God, Nation, and Individual in the Philosophy of Hegel. Philosophy and Phenomenlogical Research 2(2), pp. 188-198.

Lichtheim, G. 1967. Introduction to the Torchbook Edition. In: G.W.F. Hegel. The Phenomenology of Mind. Trans. J.B. Baillie. New York: Harper \& Row.

Mertens, T. 1995. Hegel's Homage to Kant's Perpetual Peace: An Analysis of Hegel's "Philosophy of Right". The Review of Politics 57(4), pp. 321-340.

Neuhouser, F. 2000. Foundations of Hegel's Social Theory: Actualizing Freedom. Cambridge, Mass.: Harvard University Press.

Nohl, H. (ed.). 1907. Hegels theologische Jugendschriften, nach den Handschriften der Kgl. Bibliothek in Berlin. Tübingen and Frankfurt am Main: Minerva. 
Patten, A. 1999. Hegel's idea of freedom. Oxford: Oxford University Press.

Pelczynski, Z.A. (ed.). 1971. Hegel's Political Philosophy-problems and perspectives. Cambridge: Cambridge University Press.

Philosophie des Rechts: Die Vorselung von 1819/290 in einer Nachschrift. 1983. Frankfurt am Main: Suhrkamp.

Pinkard, T. 1986. Freedom and Social Categories in Hegel's Ethics. Philosophy and Phenomenological Research 47(2), pp. 209-232.

Pippin, R.B. 2008. Hegel's practical philosophy: Rational agency as ethical life. Cambridge: Cambridge University Press.

Pippin, R.B. 2011. Hegel on Self-Consciousness: Desire and death in The Phenomenology of Spirit. Princeton, N.J.: Princeton University Press.

Ramet, P. 1983. Kantian and Hegelian Perspectives on Duty. Southern Journal of Philosophy 21(2), pp. 281-299.

Ritter, J. 1965. Hegel und die französische Revolution. Frankfurt am Main: Suhrkamp.

Senigaglia, C. 2007. Verfassungseinheit und Gewaltenausgleich: Hegels Auseinandersetzung. Parliaments, Estates and Representation 27(1), pp. 37-56.

Shklar, J.N. 1976. Freedom and Independence: A Study of the Political Ideas of Hegel's Phenomenology of Mind. Cambridge: Cambridge University Press.

Smith, S.B. 1986. Hegel's Critique of Liberalism. American Political Science Review 80(1), pp. 121-139.

Smith, S.B. 1989a. Hegel's Critique of Liberalism: Rights in Context. Chicago: University of Chicago Press.

Smith, S.B. 1989b. What is 'Right' in Hegel's Philosophy of Right? American Political Science Review 83(1), pp. 3-18.

Stillman, P.G. 1974. Hegel's Critique of Liberal Theories of Rights. American Political Science Review 68(3), pp. 1086-1092.

Stillman, P.G. 1980. Hegel's Civil Society: A Locus of Freedom. Polity 12(4), pp. 622-646.

Suter, J.F. 1971. Burke, Hegel, and the French Revolution. In: Z.A. Pelczynski (ed.). Hegel's Political Philosophy - problems and perspectives. Cambridge: Cambridge University Press, pp. 52-72.

Taylor, C. 1975. Hegel. Cambridge: Cambridge University Press.

Taylor, C. 1979. Hegel and Modern Society. New York: Cambridge University Press.

Taylor, C. 2008. Hegel. Cambridge: Cambridge University Press.

Taylor, C. 2015. Hegel and Modern Society. Cambridge: Cambridge University Press.

Tunick, M. 1998. Hegel on Justified Disobedience. Political Theory 26(4), pp. 514-535.

Westphal, K. 1993. The basic context and structure of Hegel's Philosophy of Right. In: F.C. Beiser (ed.). Cambridge Companion to Hegel. Cambridge: Cambridge University Press, pp. 234-269.

Wiedmann, F. 2003. Georg Wilhelm Friedrich Hegel. Reinbek bei Hamburg: Rowohlt Taschenbuch Verlag.

Wokler, R. 1998. Contextualizing Hegel's Phenomenology of the French Revolution and the Terror. Political Theory 26(1), pp. 33-55.

Wood, A.W. 1990. Hegel's ethical thought. Cambridge: Cambridge University Press.

Wood, A.W. 1993. Hegel's ethics. In: F.C. Beiser (ed.). Cambridge Companion to Hegel. Cambridge: Cambridge University Press, pp. 211-233. 